\title{
超伝導加速空洞の性能向上に向けた技術開発
}

\author{
梅森 健成 ${ }^{* 1,2, \dagger}$
}

\section{Development of Superconducting RF Cavities toward Higher Performance}

\author{
Kensei UMEMORI ${ }^{* 1,2, \dagger}$
}

\begin{abstract}
Synopsis: Superconducting RF technology has been developed based on electropolishing and ultra-pure water high pressure rinsing. Recently, new technologies, so-called Nitrogen doping and Nitrogen infusion, have been proposed and an improvement in cavity performance was achieved. Nitrogen doping realizes a drastic reduction in surface losses and has become the new standard for $\mathrm{CW}$ accelerators. Nitrogen infusion is another attractive technology. It has the possibility of improving the acceleration gradient too. The procedures for current standard surface treatment, Nitrogen doping and Nitrogen infusion are described, and experimental results are shown. New knowledge regarding how to handle magnetic flux to improve surface resistance is also discussed.
\end{abstract}

Keywords: accelerator, flux expulsion, Nitrogen infusion, Nitrogen doping, superconducting RF cavity

\section{1. はじめに}

ここ $20 \sim 30$ 年のニオブ製超伝導加速空洞の開発は、電 解研磨 (Electro Polishing) による空洞表面の平滑化と超純 水高圧洗浄 (High Pressure Rinse) による空洞組立工程の清 浄化をベースにした技術に支えられてきた。その集大成と 言うべき加速器が最近ドイツに建設された Euro-XFEL ${ }^{1)}$ ある。

一方で現在アメリカにて建設中の LCLS-II ${ }^{2)} に$ 向けて、こ こ数年で新しい技術開発が進んだ。窒素ドープ 3) と呼ばれ る表面処理技術と、空洞を冷却する際の磁束排除 ${ }^{4)}$ の技術 が確立され、超伝導空洞の表面抵抗の低減が実現できるよ うになった。この技術はへリウム冷凍機の低負荷運転に繋 がり CW（連続）運転を行う加速器には多大なメリットと なる。

さらに、窒素ドープから派生した技術として窒素イン フュージョン ${ }^{5)}$ と呼ばれる表面処理方法が、アメリカ・

Fermi 国立加速器研究所 (FNAL, Fermi National Accelerator

Received February 7, 2019

${ }^{* 1}$ 高エネルギー加速器研究機構 加速器研究施設

テ305-0801 茨城県つくば市大穂 1-1

Accelerator Laboratory, KEK, High Energy Accelerator Research

Organization, 1-1 Oho, Tsukuba, Ibaraki 305-0801, Japan

*2 総合研究大学院大学 高エネルギー加速器科学研究科

干240-0193 神奈川県三浦郡葉山 湘南国際村

School of High Energy Accelerator Science, SOKENDAI,

The Graduate University of Advanced Studies, Hayama,

Miura-gun, Kanagawa 240-0193, Japan

† E-mail: kensei.umemori@kek.jp

DOI: $10.2221 /$ jcsj. 54.267
Laboratory) から提唱されている。これは表面抵抗の削減の みならず加速電圧の向上も同時に目指す技術である。 ILC ${ }^{6)}$ (International Linear Collider) 計画での超伝導空洞の高電界 化に向け、筆者ら高エネルギー加速器研究機構 (KEK) の グループも FNAL との国際協力のもと研究を進めている。

超伝導加速空洞は、電子・陽子・重イオン等の様々な荷 電粒子の加速に用いられ、その用途により空洞形状、共振 周波数・運転温度などが異なる。空洞特性もそれぞれの空 洞により異なるが、本論文においては、電子ビームの加速 に用いられる代表的な $1.3 \mathrm{GHz}$ のニオブ製楕円型超伝導加 速空洞を用いた空洞高性能化のための技術開発について紹 介する。開発に用いた $1.3 \mathrm{GHz}$ 単セル空洞のうち 1 台を Fig. 1 に示す。

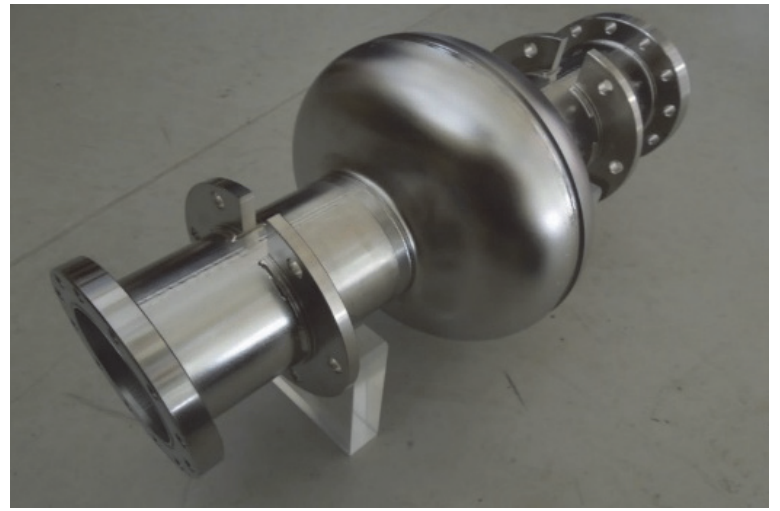

Fig. 1 An example of a $1.3 \mathrm{GHz}$ single-cell superconducting cavity. 


\section{2. 超伝導加速空洞}

\section{1 超伝導加速空洞の特徵}

加速空洞は、空洞内に電磁場を共振させ、その電場成分 を用いて荷電粒子を加速するものである。超伝導空洞の特 徵は、何と言っても超伝導であるがゆえに表面抵抗が非常 に小さいことにある。1.3 GHzのニオブ製空洞を $2.0 \mathrm{~K}$ 以 下に冷却すると表面抵抗は数〜 $10 \mathrm{n} \Omega$ 程度となり、わず か $10 \mathrm{~W}$ ほどの電力で数 $10 \mathrm{MV}$ の加速電圧を得ることが できるようになる。

加速空洞の性能は “加速勾配 $\left(\mathrm{E}_{\mathrm{acc}}\right)$ ” と “Q 值 $\left(\mathrm{Q}_{0}\right)$ ” というパラメーターで表される。加速勾配は、単位長さ当 たりの加速電圧であり、超伝導空洞の場合は $\mathrm{MV} / \mathrm{m}$ の単 位で表される。加速勾配が大きい方が、少ない台数の空洞 で大きな加速が得られる。1.3 GHzの 9 セル空洞の場合だ と空洞長さはほぼ $1 \mathrm{~m}$ である。 $\mathrm{Q}$ 值は $\mathrm{Q}_{0}=2 \pi \mathrm{f} \times \mathrm{U} / \mathrm{P}$ で表される。f は共振周波数、U は空洞内電磁場の蓄積エ ネルギー、P が表面損失である。空洞形状が同じ場合は、 $\mathrm{Q}$ 值の高い空洞と低損失の空洞は同義であり、表面抵抗と $\mathrm{Q}$ 值とは反比例の関係にあるパラメーターである。

我々の目指寸超伝導空洞の高性能化とは、“より高い加 速勾配” “より高い Q 值（より低い損失）”の実現を目的 とするものである。

\section{2 ニオブの表面抵抗}

$1.3 \mathrm{GHz}$ ニオブ製超伝導空洞を冷却する際の表面抵抗 $\left(\mathrm{R}_{\mathrm{S}}\right)$ の温度依存を Fig. 2 に示す。冷却とともに指数関数 的に下がって行く $\mathrm{BCS}$ 抵抗 $\left(\mathrm{R}_{\mathrm{BCS}}\right)$ と定数項として表され る残留抵抗 $\left(\mathrm{R}_{\mathrm{res}}\right)$ の和で表される。1.3 $\mathrm{GHz}$ の超伝導空洞 は、液体ヘリウムの冷却効率も考慮して $2.0 \mathrm{~K}$ 付近で運転 されるので、BCS 抵抗と残留抵抗の両方が寄与する。

高い $\mathrm{Q}$ 值を目指すには、二通りの方法がある。ひとつ は BCS 抵抗を下げる方法で、窒素ドープはこれを実現す る手法である。もうひとつは残留抵抗を下げる方法である。 残留抵抗にはニオブ材料・表面処理方法に起因した抵抗と ともに、冷却時にニオブに捕捉された磁場の影響が含まれ

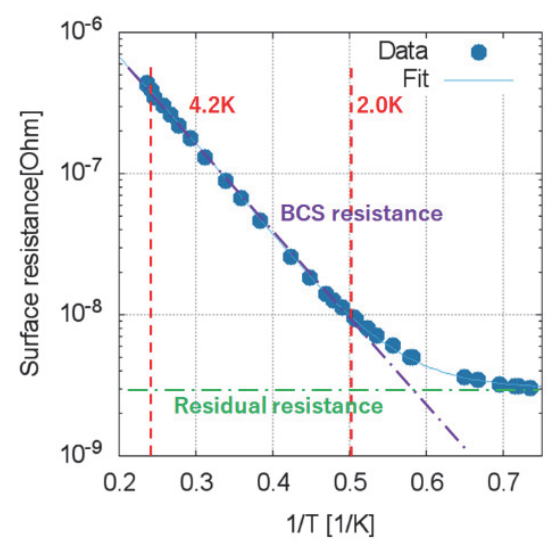

Fig. 2 Temperature dependence of surface resistance on a $1.3 \mathrm{GHz}$ niobium superconducting cavity.
る。捕捉磁場の空洞性能への影響もここ数年で飛躍的に理 解が進んだ。磁束排除による高 $\mathrm{Q}$ 值の実現については 6 章にて述べる。

\section{$2.3 \mathrm{CW}$ 運転とパルス運転}

これまで述べてきたように表面損失が小さいのが超伝導 空洞の特徴であるが、そのためにはへリウム冷凍機を用い て冷却し続ける必要がある。ヘリウム冷凍機の運転には、 空洞表面の熱負荷の数百倍もの電力を必要とするため、超 伝導加速器の全体構成を考える際は、冷凍機負荷を含めた 全体のバランスを良く検討する必要がある。

電力における $\mathrm{P} \propto \mathrm{V}^{2}$ の関係と同様に、超伝導空洞の表 面損失は加速勾配の 2 乗に比例する。10 MV/m の運転と $30 \mathrm{MV} / \mathrm{m}$ の運転を比較すると、後者の運転には実に 10 倍 近い冷凍能力を要する。

ILC のように高いエネルギーを必要とする加速器では、 $30 \mathrm{MV} / \mathrm{m}$ を超える高加速勾配での運転を行うが、冷凍機 負荷が膨大な量になるのを避けるため $1 \%$ 程度の duty での パルス運転を行い、負荷を軽減する。一方で大電流運転を 狙う ERL（エネルギー回収型リニアック）や CW-FEL （自由電子レーザー）の場合には、CW 運転が必須である。 この場合には、空洞台数は増えるが、加速勾配を下げて 10〜 $15 \mathrm{MV} / \mathrm{m}$ 程度の加速勾配で運転することで冷凍機負 荷を最適化している。

\section{3. 超伝導加速空洞の表面処理と性能}

\section{1 超伝導加速空洞の性能を制限する要因}

超伝導空洞の敵となるのは磁場と熱である。ニオブ表面 が臨界磁場を超えるか、臨界温度を超えると超伝導状態が 破壊されクエンチを起こす。

加速電圧を上げていくと、空洞内部の電磁場が強くなっ ていくが、次の章で述べるように標準的な電解研磨を施し た空洞の場合だと $180 \mathrm{mT}$ 程度の磁束密度に到達したとこ ろでクエンチを引き起こす。一方で、空洞内部に欠陥があ る場合、特にエッジが立った欠陥があるとそこに磁場が集 中し、十分高い加速勾配に到達する前にクエンチを起こ す。高性能を得るためには欠陥の無いニオブ表面を作るこ とが重要である。

また、ニオブ表面で異常な発熱があると温度上昇を起こ し、臨界温度（9.2 K）を超えるとクエンチを起こす。空洞 内の電界の高い場所に $\mu \mathrm{m}$ からサブ $\mu \mathrm{m}$ の大きさのダス トが存在すると、電界放出 (Field emission) を起こす。電 界放出により放出される電子が、二オブ表面にぶつかると 発熱を起こす。加速勾配とともに放出電子は指数関数的に 増えていき、最終的にクエンチを引き起こす。電界放出を 避けるためには、空洞アセンブリの際に空洞内にダスト・ ゴミを入れないよう十分注意して作業を行うことが重要で ある。空洞表面に常伝導の異物が存在する場合にも発熱に よるクエンチを引き起こす。この点からも欠陥・異物の無 
いきれいなニオブ表面を作ることは重要である。

\section{2 超伝導加速空洞の標準表面処理レシピ}

一般にニオブ製超伝導空洞は、ニオブ板をプレスして お椀型のハーフセル形状に成型したものを、電子ビーム溶 接にて接合して製造される。上で述べたように、製造工程 にてニオブ表面に傷や異物混入、溶接欠陥が無いよう各工 程での清浄度の確保も含めて非常に気を使って製造され る。

製造された超伝導加速空洞に対する標準的な表面処理レ シピを以下に示す。

1) 多量電解研磨 $(100 \sim 200 \mu \mathrm{m})$

2) 真空炉にて高温熱処理（800〜900 度、3 時間）

3）共振周波数調整（空洞の塑性変形による）

4) 仕上げ電解研磨 $(20 \mu \mathrm{m}$ 程度 $)$

5) 超音波洗浄 (15 分)

6) 超純水高圧洗浄（3～6 時間程度）

7) クリーンルームにて縦測定用アセンブリ作業

8) ベーキング（120 度、48 時間）

前半 1)〜5) は、空洞表面を鏡面に近い滑らかな表面に仕 上げるための工程である。高い加速勾配が得られる電解研 磨が用いられることが多いが、空洞形状や要求性能によっ ては化学研磨等の処理方法を適用する場合もある。処理の 途中で欠陥が見つかった場合には、局所的に研磨する等の 対応を随時行っている。途中に入る熱処理は、空洞に悪影 響を及ぼす水素の脱ガスと空洞にため込んだ応力除去の効 果がある。6)，7）の作業はクリーンルームでの作業とな る。まずは超純水高圧洗浄にて空洞内のダストを吒き落と した後、ダストの混入の無いよう細心の注意を払いながら 空洞に測定用のフランジを取り付けるアセンブリ作業を行 う。組み立てた空洞は真空に引かれて、最後に 120 度での ベーキングを行うと空洞性能評価のための縦型ピットにお ける低温試験（縦測定と呼ばれる）の準備が整う。

\section{3 ベーキングの効果}

上記で述べたベーキングの効果は、実は脱ガスを促し超 高真空を得ることだけにとどまらない。Fig. 3 にベーキン グ有りの場合と無しの場合の縦測定結果を示す。ベーキン グをしない場合だと 25〜30 MV/m のあたりから Q 值が下 がってくる HFQS (High Field Q-slope) という現象を示す。 一方でベーキングを行った空洞は、高い加速勾配まで高い $\mathrm{Q}$ 值を保持する結果となる。

HFQS およびベーキングの効果について明確に理解され ている訳ではないが、ニオブ中に残留している水素が、冷 却の過程において、空洞表面付近に常伝導体である水素化 物を形成することが HFQS の原因ではないかと考えられて いる ${ }^{7)}$ 。電解研磨直後に二オブ表面は酸化膜で覆われる が、ベーキングを行うことにより、酸素がニオブの奥の方 向に拡散していくと考えられる。ベーキングをした空洞の 場合に HFQS が起こらないのは、この拡散した酸素がニオ

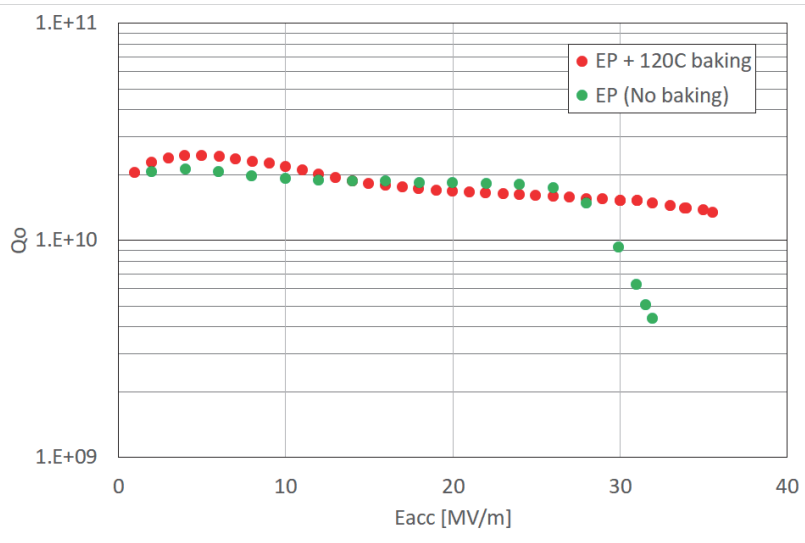

Fig. 3 Comparison of cavity performance with and without baking after electropolishing.

ブ表面付近での水素化物生成を阻害するからではないかと 考えられている。120 度ベーキングも超伝導空洞の性能向上 を実現するうえで非常に重要な役割を担っているのである。

\section{4. 窒素ドープ}

\section{1 真空炉}

KEK における窒素ドープの研究は、超伝導空洞の標準処 理における熱処理用に整備された油拡散ポンプを用いた真 空炉にて始められた。しかし、残念ながら窒素ドープを施 すと毎回 Q 值が下がってしまうという結果となり、失敗に 終わった ${ }^{8)}$ 。この結果から、窒素ドープならびに窒素イン フュージョンに用いる真空炉には高い清浄度が必要であ る、という教訓が得られた。

窒素ドープおよび窒素インフュージョンの研究を本格的 に推進するにあたって 2017 年度は J-PARC 真空グループの 真空炉をお借りした。2018 年度からは KEK に設置した新 しい真空炉を用いた（Fig. 4）。メインの排気系はクライオ ポンプであり、粗排気も含めオイルフリーの真空排気系が 構築されている。またヒーター・反射板・ステージなど真 空炉内の高温部の材料にはモリブデンを用いた。空洞の出 し入れを行う真空炉の屝部分はクリーンブースで覆われ、

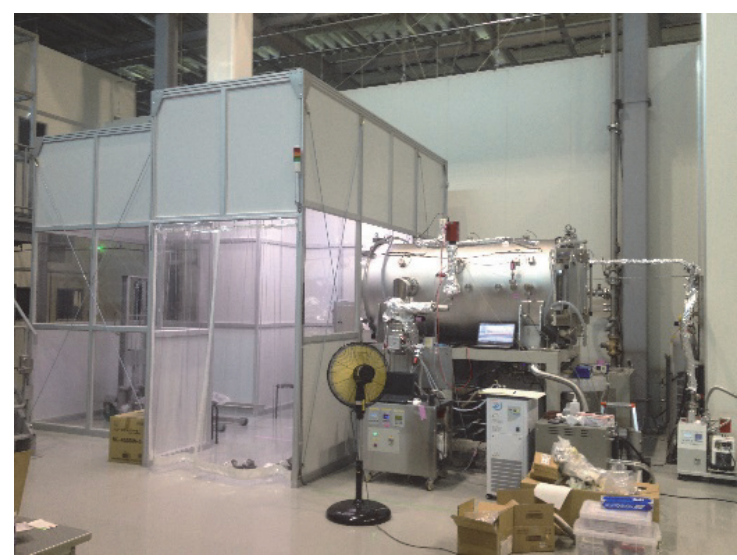

Fig. 4 Vacuum furnace dedicated to superconducting cavities, constructed at KEK. 
清浄な環境下での空洞への作業を可能にしている。真空炉 は不要な污染を避けるためニオブ空洞専用で運用されてい る。2017 年度に用いた J-PARC の真空炉もクライオポンプ を用いたオイルフリーの清浄度の高い真空炉である。

\section{2 窒素ドープのプロセス}

窒素ドープは、Q 值の向上を目指寸処理方法である。Q 值が向上寸る一方で、加速勾配は 20〜 $25 \mathrm{MV} / \mathrm{m}$ 程度に制限 されるというデメリットがあるが、高加速勾配を要求しな い $\mathrm{CW}$ 加速器においては、低負荷運転を実現できるという 点で非常に魅力的である。LCLS-II では、窒素ドープ処理 を施した空洞を用いて実際に建設が始まっている。

窒素ドープは 3 章で述べた標準表面処理レシピのうち、 高温熱処理の工程の際に微量の窒素ガスを導入するもので ある。Fig. 5 に窒素ドープにおける真空炉の温度と真空度 の履歴を示す。以下、真空炉における窒素ドープの典型的 処理工程を示す。

1) 800 度まで昇温後、3 時間保持

2) 800 度で、2(20)分間 $3.3 \mathrm{~Pa}$ の窒素を真空炉に導入

3) 真空に引き戻し、800 度で 6(30)分間保持

4) 常温まで自然冷却

窒素ドーププロセスでは、800 度への高温熱処理できれ いなニオブ表面を作ったところに窒素を導入して表面に窒 素を取り込む、この後の 800 度保持では、取り込んだ窒素 を空洞内部一拡散させている。この処理工程の時間や圧力 を変えるとニオブ表面での窒素濃度や梁さ方向の分布が変 わり、Q值や加速勾配が変わる。

\section{3 窒素ドープにおけるニオブ表面}

我々は、真空炉での空洞の熱処理の際に一緒にニオブサ ンプルを入れて表面状態を調べている。Fig. 6 に GD-OES (グロー放電発光分析装置) で測定した窒素ドープサンプ ルの一例を示す。深さとともに急速に減衰する最表面の窒 化ニオブの層と、数 $\mu \mathrm{m}$ の深さからの比較的深さ方向にフ ラットな窒素が拡散した層が特徵的であり、窒素は数 10 $\mu \mathrm{m}$ の梁さまで拡散している ${ }^{9}$ 。

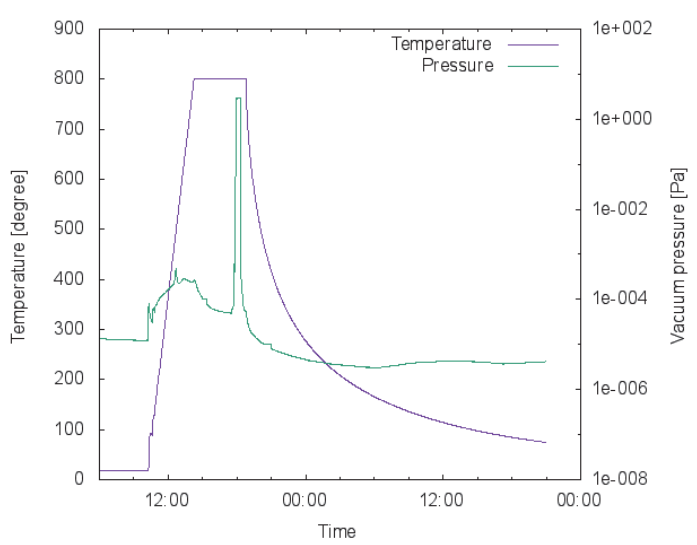

Fig. 5 Temperature and vacuum pressure of the furnace during Nitrogen doping process.

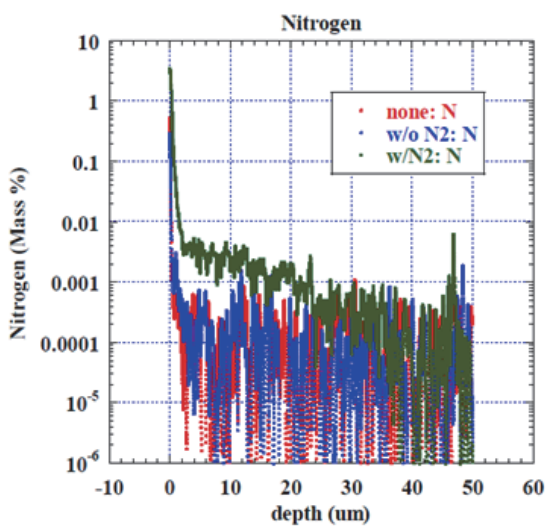

Fig. 6 Depth profile of the nitrogen as observed using GD-OES. Measurement results for only electropolishing (shown as "none"), heat treatment without Nitrogen (w/o $\mathrm{N}_{2}$ ) and Nitrogen doping sample $\left(\mathrm{w} / \mathrm{N}_{2}\right)$.

ニオブ製超伝導空洞の $\mathrm{Q}$ 值向上に寄与するのは、この窒 素が拡散した層である。最表面の窒化二オブは性能向上に 寄与しないので、真空炉にて窒素ドープを行った後は、最 適な厚さを電解研磨にて除去する。なお窒素ドープ表面を 保持するため、空洞アセンブリ後の 120 度ベーキングは行 わない。

\section{4 窒素ドープを施した空洞の測定結果}

窒素ドープを施した $1.3 \mathrm{GHz}$ 単セル空洞の縦測定結果を Fig. 7 に示す。第 6 章で磁場について議論するが、この測 定では磁気シールドと磁場キャンセル用ソレノイドコイル を用いて、空洞への磁場の影響を極力排除している。窒素 ドープの結果として、それぞれの測定温度で、特に加速勾 配が上がるにつれ Q 值が向上していることが見て取れる。

Fig. 8 に、BCS 抵抗の加速勾配依存性を示寸。ここに見 られるように加速勾配が大きくなるに連れて、BCS 抵抗が 下がるのが窒素ドープ空洞の最大の特徴である。

6.3 節に後述するが、標準処理の空洞と比べて窒素ドー プの空洞は捕捉磁場の影響を受けやすく、容易に残留抵抗 が大きくなる可能性を秘める。実際にビーム運転を行う加

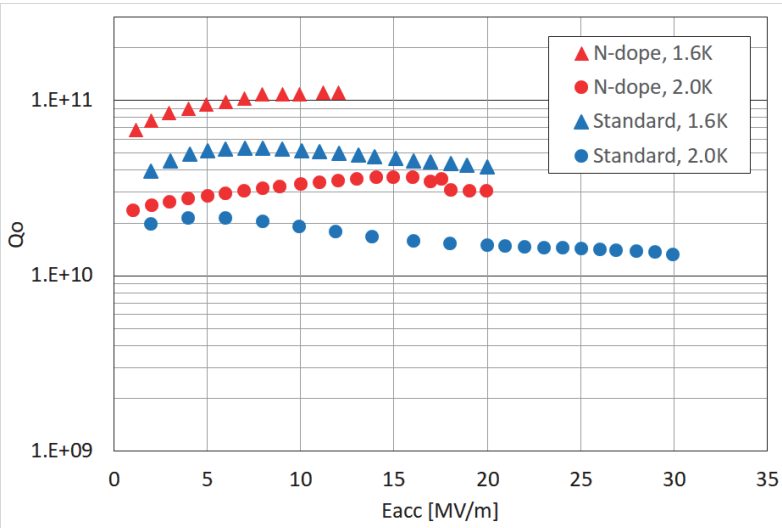

Fig. 7 Comparison of cavity performance when applying Nitrogen doping (N-dope) and standard recipe (standard). 


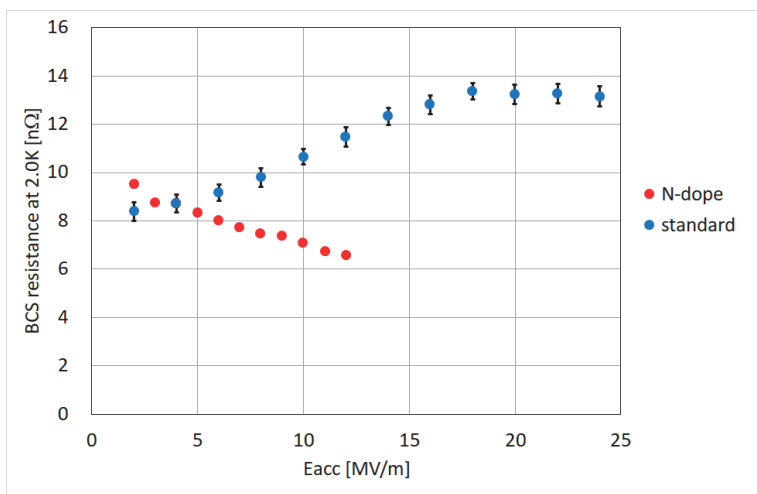

Fig. 8 Comparison of BCS resistance of cavities at 2.0 K when applying Nitrogen doping (N-dope) and standard recipe (standard).

速器においては、どれだけ周辺磁場のコントロールができ るかも、高 $\mathrm{Q}$ 值を達成する上で重要な鍵を握る。

\section{5. 窒素インフュージョン}

\section{1 熱処理における空洞の取り扱い}

窒素インフュージョンは 120 度の低温で時間をかけて窒 素を空洞に取り込む処理であり、ニオブのごく表面数 $\mathrm{nm}$ 程度のところに影響を与える。そのため電解研磨等の後処 理をすることができない。このことは真空炉での熱処理が 十分清浄な環境下で行われ、空洞内部を污染するようなこ とがあってはならない、という厳しい条件が課せられてい ることを意味する。

熱処理時に空洞内部を污染しないように、空洞の扱いに も気を使っている。まず、熱処理前に超純水高圧洗浄にて 空洞内部のダストを除去する。空洞はクリーンルーム内で 乾燥させ、パッキングされた状態で、真空炉のクリーンブー スまで移動する。熱処理時には Fig. 9 にあるように、ニ才 ブ製のキャップおよびニオブ䇴を空洞フランジ部に被せて いる。これは真空炉のヒーター等から污染物質が直接空洞 内部に飛び込んでくるのを避けるためである。窒素ガスが

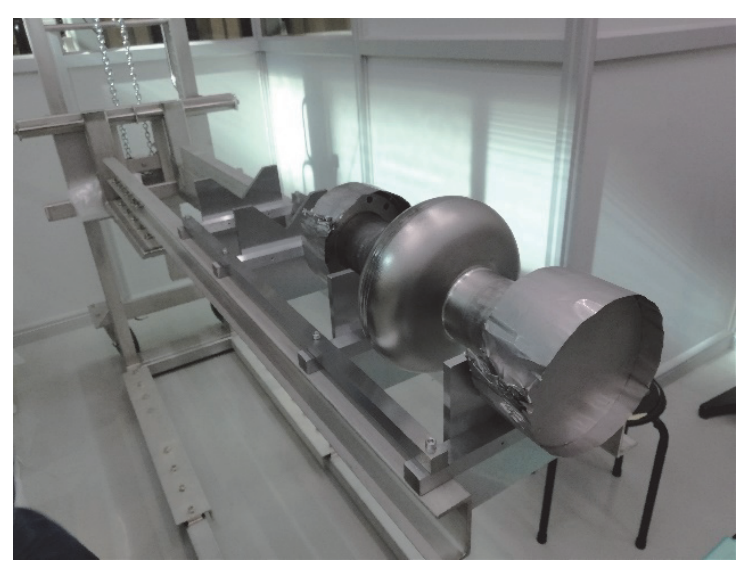

Fig. 9 Setup of cavity, which will be installed into the furnace.
空洞内部に入るだけの十分な隙間は確保している。

\section{2 窒素インフュージョンのプロセス}

窒素ドープが $\mathrm{Q}$ 值のみの向上であったのに対し、窒素 インフュージョンは Q 值も加速勾配も向上させようという 試みである。Fig. 10 に FNAL での窒素インフュージョンの 結果を引用する。ILC のように高い加速勾配を要求される 加速器への応用が期待されている。

窒素インフュージョンも真空炉での高温熱処理の際に窒 素を導入する処理工程であるが、窒素ドープの場合に 800 度 で窒素を入れたのに対し、窒素インフュージョンは 120 度 の比較的低温で窒素を導入する。Fig. 11 に窒素インフュー ジョンでの温度と真空度の履歴を示す。以下、真空炉を用 いた窒素インフュージョンの典型的処理工程を示す。

1) 1800 度まで昇温後、3 時間保持

2) 120 度まで降温（真空のまま）

3) 120 度で、48 時間、3.3 Pa の窒素を真空炉に導入

4) 真空に引き戻し、常温まで自然冷却

窒素インフュージョンプロセスでは、120 度の低い温度 でゆっくり時間をかけながら、窒素の取り込みと拡散を行

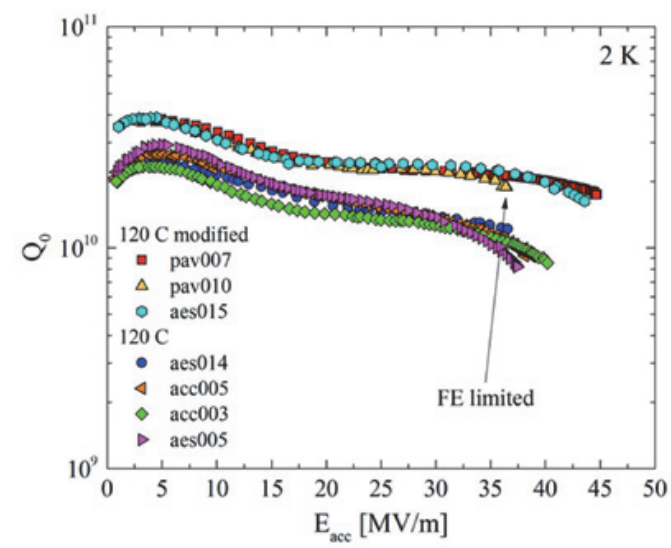

Fig. 10 Results of Nitrogen infusion measured at FNAL. Cited from a paper ${ }^{5}$.

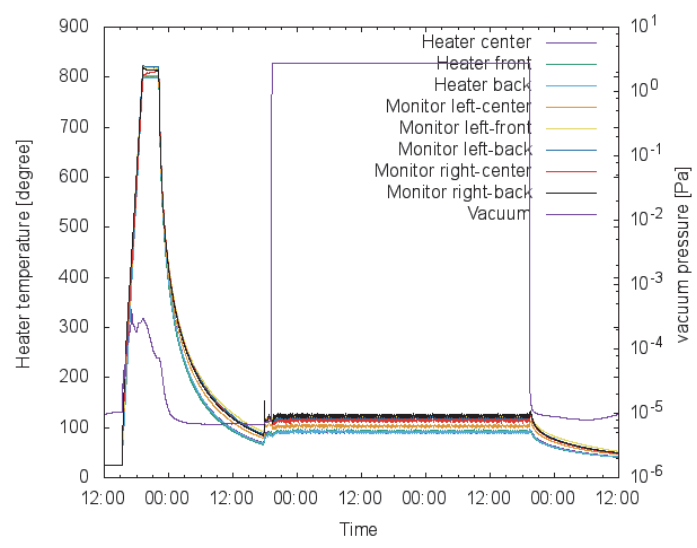

Fig. 11 Temperature and vacuum pressure of the furnace during Nitrogen infusion process. 

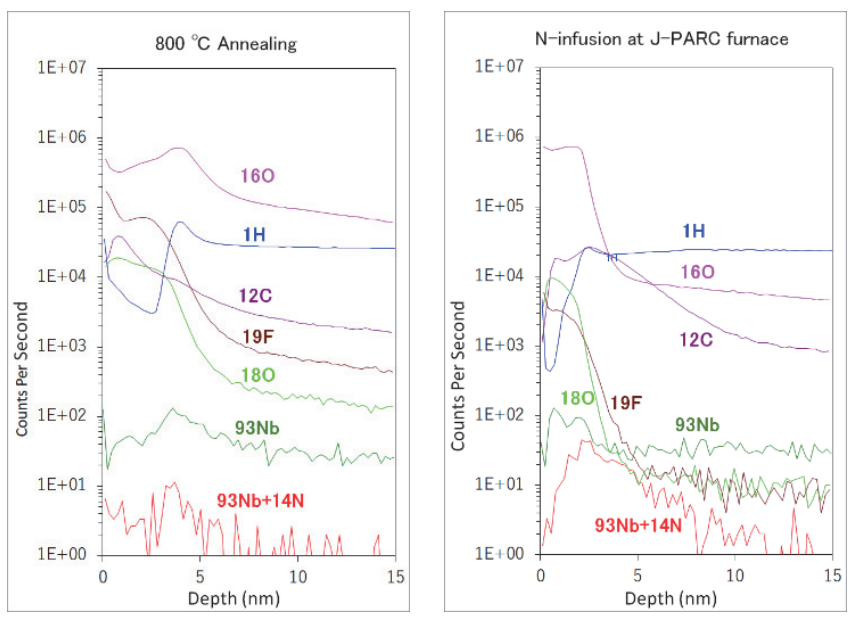

Fig. 12 Surface analysis carried out using SIMS for heat treatment without Nitrogen (left) and Nitrogen infusion (right).

う。窒素導入時の温度や時間を変えると、Q 值の振る舞い が変化する。

\section{3 窒素インフュージョンにおけるニオブ表面}

窒素インフュージョンの場合も、真空炉での空洞の熱処 理の際に一緒にニオブサンプルを入れて表面状態を調べて いる。Fig. 12 に SIMS（二次イオン質量分析法）で測定し た窒素インフュージョンサンプルならびに通常熱処理サン プルの表面分析結果の一例を示す。正直なところあまり違 いは見えていない。どちらのサンプルとも表面数 $\mathrm{nm}$ のと ころは酸化膜で覆われていて、窒素の効果は非常にわずか である。何が性能向上に寄与しているのかは現状定かで無 く、今後の研究での解明が待たれる。

なお窒素インフュージョン表面を保持するため、空洞ア センブリ後の 120 度ベーキングは行わない。

\section{4 窒素インフュージョンを施した空洞の測定結果}

窒素インフュージョンを施した $1.3 \mathrm{GHz}$ 単セル空洞の縦 測定結果を Fig. 13 に示す。この測定結果も窒素ドープの時 と同様に、磁気シールドと磁場キャンセル用ソレノイドコ イルを用いて、空洞への磁場の影響を極力排除している。 窒素インフュージョンの結果として Q 值が多少向上してい るが、加速勾配は下がってしまっている。30 MV/m 以上で の $\mathrm{Q}$ 值の劣化は電界放出によるものである。

まず窒素インフュージョンにより HFQS が克服されて いる点は重要である。なお、KEK での実験では窒素イン フュージョンによる Q 值の向上は何例か確認されている が、加速勾配の向上までがなかなか再現性よく確認されて いない。

さらに Fig. 14 に示されるように $5 \mathrm{MV} / \mathrm{m}$ 付近から Q 值 が劣化するという現象がしばしば観測される。原因は真空 炉からの污染であろうと考えているが、これらの課題を克 服して、再現性良く Q 值・加速勾配の向上を実現できるよ う鋭意努力しているところである。

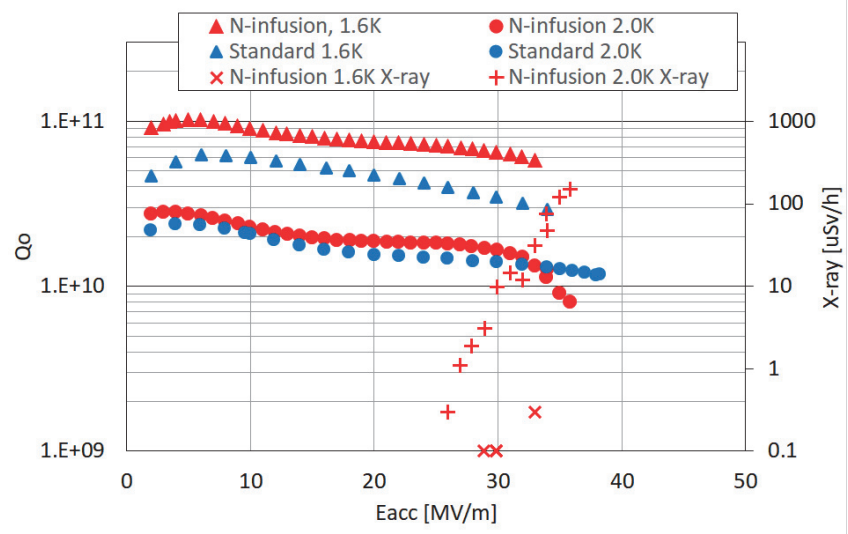

Fig. 13 Comparison of cavity performance between successful Nitrogen infusion (red) and standard recipe (blue).

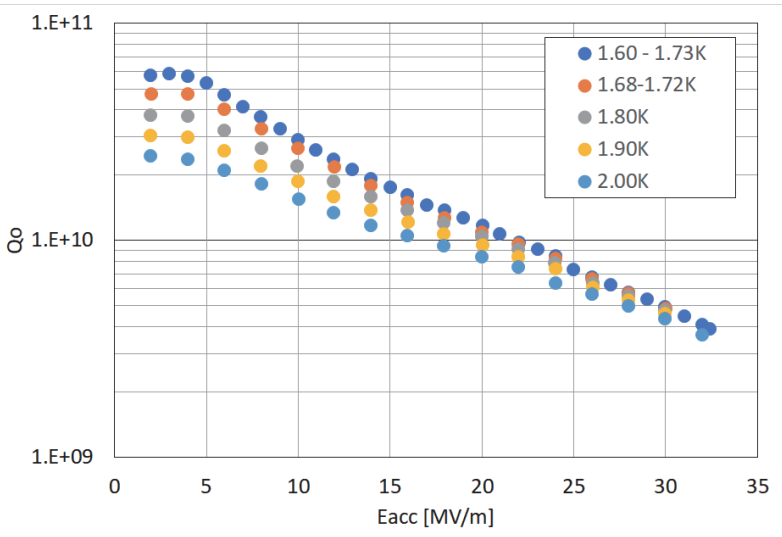

Fig. 14 Cavity performance when Nitrogen infusion failed.

窒素ドープの場合ほど捕捉磁場の影響は受けないが、 ビーム運転を行う加速器に用いる場合には、磁場の影響を 十分検討しておく必要がある。

\section{6. 超伝導加速空洞への磁束捕捉/磁束排除}

\section{1 超伝導加速空洞と周辺磁場}

ニオブ製超伝導空洞への磁場の影響が系統的に理解さ れ、 $1 \times 10^{11}$ というような高い $\mathrm{Q}$ 值が定常的に得られるよ うになったのは、実はここ数年のことである。それまでも 磁気シールドにて磁場遮蔽をしてはいたが、10 mG 程度も しくはそれ以上の磁場環境のもとで、超伝導空洞の測定な らびに加速器としての運用が行われることが多かった。窒 素ドープ処理が確立して BCS 抵抗の低い高 Q 值の空洞が 実現されるとともに、磁場の影響による残留抵抗がクロー ズアップされることとなった。

縦測定と呼ばれる空洞単体の試験においては、ゼロ磁場 に近い理想的な環境を整えることはそれほど難しくない が、加速器としてビーム運転を行うためのクライオモジュ ールでは 5〜10 mG 程度の磁場の中で運用を行うことにな るので、磁場の抑制・磁場に対する制御方法を確立するこ 
とは、加速器全体としての低負荷運転を実現するうえで重 要である。そもそも磁化した（磁化し得る）コンポーネン トを用いないこと、磁気シールドで出来る限り磁気遮蔽す ることは大前提である。

\section{2 効率的な磁束排除の手法}

ニオブは第 2 種超伝導体であり、冷却時に常伝導から超 伝導に転移する際に、空洞を貫く磁束を捕捉し得る。通常 の表面処理方法および冷却方法では、実はかなりの量の磁 束を捕捉していたことがわかってきた ${ }^{4)}$ 。

これまでの研究から、冷却時の磁束排除の手法も確立し つつある。磁束排除に効率的なのは、(1)900～950 度の高い 温度での空洞熱処理を行うこと、(2)冷却時に空洞表面に温 度勾配をつけること、である。

Fig. 15 に磁束排除実験の際のセットアップを、Fig. 16 に 熱処理温度を変えた空洞に対しての、冷却時の磁束排除の 温度勾配依存性を示す。Fig. 16 における温度差は、Fig. 15 における赤道部とアイリス部に設置したシリコン温度計の 間の温度差を示してある。二オブ材料の製造会社によって 多少の違いはあるが、熱処理温度を高くすることは磁束排 除の状況を劇的に改善する。磁束捕捉のメカニズムについ ても現在研究を進めているところであるが、高温での熱処
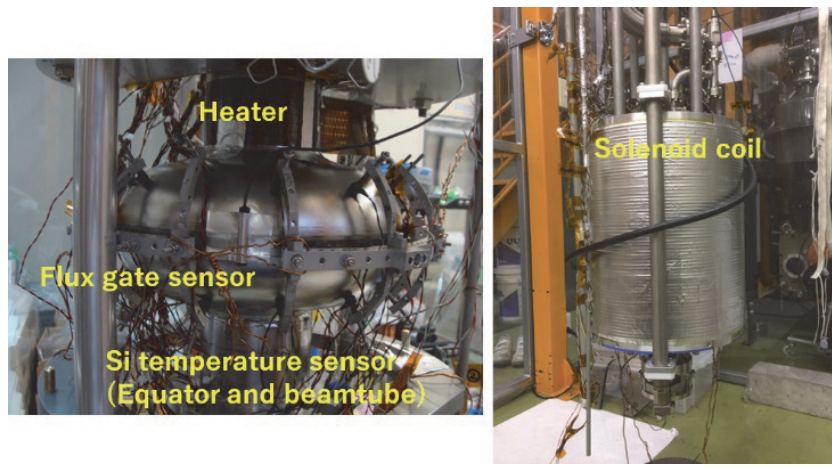

Fig. 15 The experimental setup for flux expulsion.

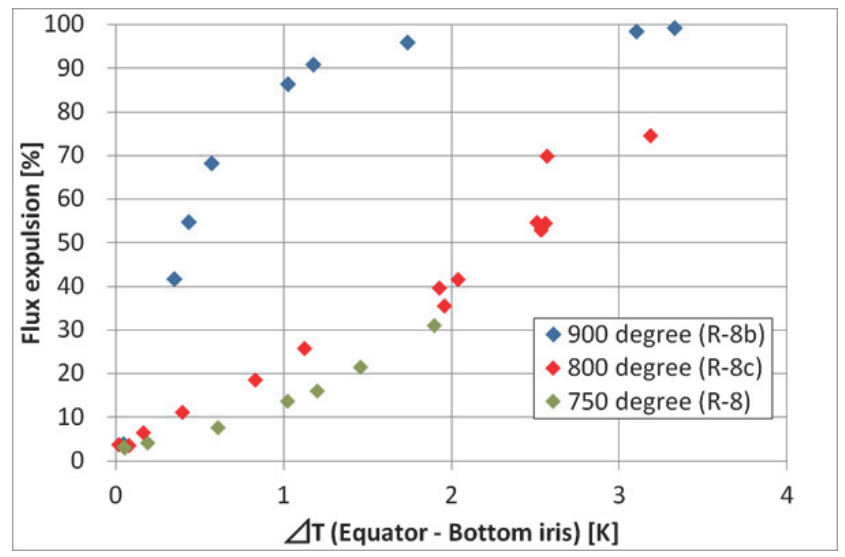

Fig. 16 Flux expulsion of cavities applied with different heat treatment temperatures. Dependence on temperature gradient during cooldown is shown.
理により格子久陥および応力歪みが減少することが一因で ないかと考えられている。冷却時の温度勾配への依存性に ついては、温度勾配が高いと超伝導に転移する際の混合状 態の領域が小さくなるため、磁束捕捉の確率が減ることに よるのではないかと考えられている。

\section{3 捕捉された磁束と残留抵抗との関係}

ビーム運転に用いるクライオモジュールにおいては、理 想的な磁場環境を整えることがなかなか困難であることか ら、冷却時に捕捉された磁束の残留抵抗への影響を調べて おくことは大事である。

縦測定において、(1)ソレノイドコイルで残留磁場をキャン セルし、かつ温度勾配による磁束排除を行った場合、(2) ソ レノイドコイルで磁場を付与し合計 $20 \mathrm{mG}$ の磁場環境下で 温度勾配をつけずに冷却した場合、の 2 通りを比較し、捕 捉された磁束の影響を調べている。

Fig. 17 に窒素ドープ処理の空洞に対する上記の 2 通りの 測定結果を示す。 $\mathrm{Q}$ 值に対し大きな影響を及ぼしているこ とがわかる。捕捉された磁束により残留抵抗が増して、Q 值の低下に繋がっている。Fig. 18 はそれぞれの処理の空洞 に対して、捕捉した磁束が生じさせる残留抵抗の大きさを 評価したものである。1 $\mathrm{mG}$ の捕捉磁場に対し何 $\mathrm{n} \Omega$ の残留

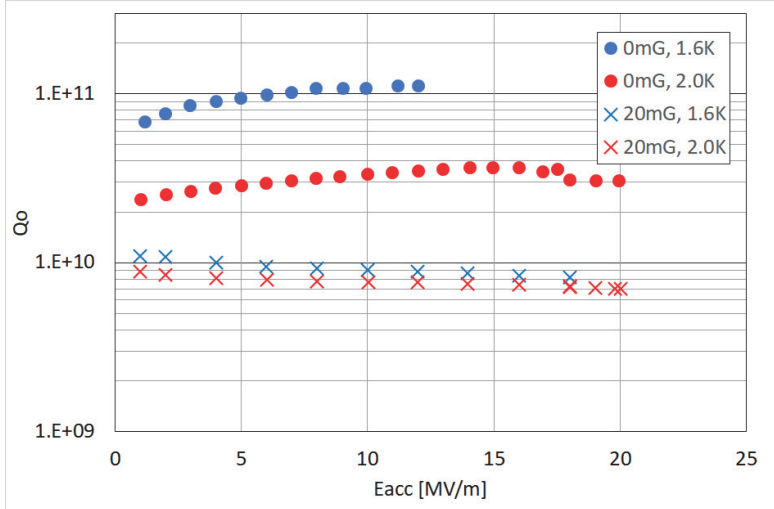

Fig. 17 Effect of trapped magnetic flux on Nitrogen doped cavity.

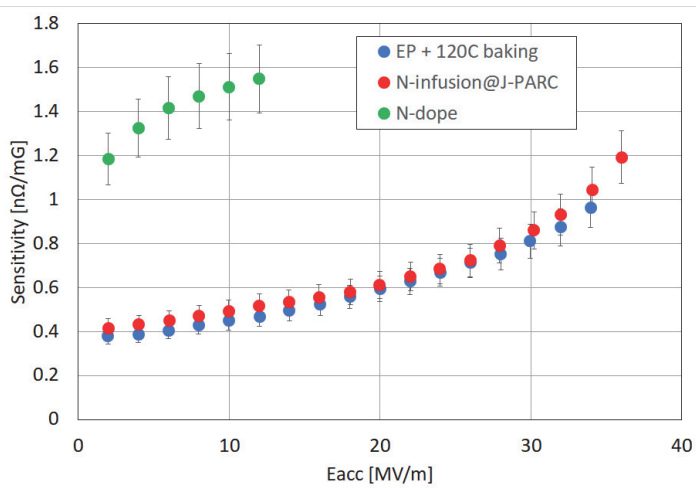

Fig. 18 Effect of trapped magnetic flux on residual resistance for different surface treatment procedures. 
抵抗を生じさせるか、を示してある。窒素ドープの空洞の 残留抵抗に対する捕捉磁場の影響は、標準処理の空洞の 3 倍近くある。窒素ドープ空洞を用いる場合は、磁場の影響 を低減できるようニオブ材料の選定、磁気シールドの設 計、周辺コンポーネントの材質の選定、冷却方法の最適化 など様々な工夫を凝らす必要がある。

\section{7. おわりに}

超伝導加速空洞のこれまでの技術は、電解研磨と超純水 高圧洗浄に支えられて進展してきており、Euro-XFEL のよ うな大型加速器が建設・運転されるまでに成熟してきた。 その一方、超伝導加速空洞のさらなる高性能化に向け、こ こ数年で窒素ドープ、窒素インフュージョンなどの新たな 表面処理方法が提案され、空洞開発も新たな局面を迎える に至った。これらの技術開発は、ニオブの電解研磨表面の 限界と思われていた性能を打ち破るものであり、ニオブ表 面を最適化することで、さらなる性能向上を実現する余地 が残されていることを示している。今後、どこまで超伝導 加速空洞の技術が進展していくか、非常に楽しみである。

\section{参 考 文 献}

1) W. Singer, et al.: "Production of superconducting 1.3-GHz cavities for the European X-ray Free Electron Laser," Phys. Rev. Accel. Beams 19 (2016) 092001

2) J. N. Galayda: "The new LCLS-II project: status and challenges," Proceedings of $27^{\text {th }}$ Linear Accelerator Conf., Geneva, Switzerland (2014) 404-408

3) A. Grassellino, et al.: "Nitrogen and argon doping of niobium for superconducting radio frequency cavities: pathway to highly efficient accelerating structures", Supercond. Sci. Technol. 26 (2013) 102001

4) S. Posen, et al.: "Efficient expulsion of magnetic flux in superconducting radio frequency cavities for high Qo applications," J. Appl. Phys. 119 (2016) 213903

5) A. Grassellino, et al.: "Unprecedented quality factors at accelerating gradient up to $45 \mathrm{MV} / \mathrm{m}$ in Niobium superconducting resonators via low temperature Nitrogen infusion," Supercond. Sci. Technol. 30 (2017) 094004

6) T. Behnke, et al.: "The International Linear Collider technical design report," www.linearcollider.org/ILC/Publications/TechnicalDesign-Report

7) A. Romanenko, et al.: "Proximity breakdown of hydrides in superconducting niobium cavities," Supercond. Sci. Technol. 26 (2013) 035003

8) K. Umemori, et al.: "Vertical test results of Nitrogen doped SRF cavities at KEK," Proceedings of $7^{\text {th }}$ International Particle Accelerator Conference, Busan, Korea (2016) 2154-2157

9) K. Umemori, et al.: "Design and commissioning of KEK new vacuum furnace for SRF cavity development," Proceedings of $29^{\text {th }}$ Linear Accelerator Conf., Beijing, China (2018) 496-498

10) T. Konomi, et al.: "Niobium sample analysis for Nitrogen infusion and doping," Proceedings of $29^{\text {th }}$ Linear Accelerator Conf., Beijing, China (2018) 506-509

11) A. Romanenko, et al.: "Ultra-high quality factors in superconducting niobium cavities in ambient magnetic fields up to $190 \mathrm{mG}$," Appl. Phys. Lett. 105 (2014) 234103

12) T. Kubo: "Flux trapping in superconducting accelerating cavities during cooling down with a spatial temperature gradient," Prog. Theor. Exp. Phys. (2016) 053G01

梅 森 健 成

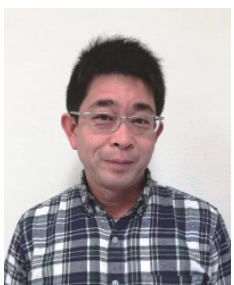

1970 年 1 月 18 日生。1994 年京都大学理学 部物理学科卒業。1999 東京大学大学院理学研 究科博士課程（物理学専攻）修了。1999 年広 島大学放射光科学センター勤務。2002 年より 高エネルギー加速器研究機構勤務。主に超伝 導加速空洞の開発に従事。加速器学会, 放射 光学会会員。理学博士。 